\title{
Ocular Applications of Dipyridamole: A Review of Indications and Routes of Administration
}

\author{
Moshe Rogosnitzky, ${ }^{1,2}$ Itzhak Isakov, ${ }^{1}$ Wjatschesslaw Wlassoff, ${ }^{2}$ April Ingram, ${ }^{2}$ and Y. Robert Barishak $^{1}$
}

\begin{abstract}
Dipyridamole was introduced decades ago as a treatment for angina, subsequently found to inhibit platelet aggregation. It is most commonly used, and approved for use in thromboembolism prevention, following surgery. Some of its recognized effects such as adenosine uptake inhibition, elevation of cAMP and cGMP levels, vasodilation, and tissue perfusion are important in various ocular disorders. For this reason, dipyridamole represents an interesting candidate as a therapeutic target for the treatment of eye disorders affecting different ocular structures. The aim of this article is to review the evidence and current understanding of the mechanisms by which dipyridamole exerts its effects on different ocular tissues, discuss the role of dipyridamole in clinical practice, and highlight areas of use and routes of administration.
\end{abstract}

\section{Introduction}

D IPYRIDAMOLE WAS INTRODUCED in the early 1960s as a coronary vasodilator, most often administered orally, and is currently approved in the United States for prophylactic thromboembolism prevention following surgery. ${ }^{1}$ As a platelet inhibitor, indicated for the secondary prevention of transient ischemic attack, it inhibits the enzyme phosphodiesterase due to inhibition of the adenosine transporter and elevates cAMP and cGMP levels, preventing platelet aggregation. ${ }^{2,3}$ Moreover, dipyridamole plays a role in the platelet inhibitory actions of prostacyclin (PGI2) and inhibits cellular uptake and metabolism of adenosine, also related to platelet aggregation, through potential stimulation of the adenylyl cyclase in platelets, resulting in elevated cAMP. ${ }^{2}$ Used in combination with aspirin, it prevents the reoccurrence of myocardial infarctions. 4

In addition to the established antithrombotic activity, studies suggest that dipyridamole provides beneficial properties to the vasculature, including both direct and indirect effects to the endothelium. Endothelial effects include inhibition of proliferation, antioxidant, and anti-inflammatory properties, as well as their subsequent effect on cell signaling. ${ }^{5}$ The inhibition of the reuptake of adenosine into platelets, endothelial cells and red blood cells by dipyridamole results in increased extracellular concentrations of adenosine into the cytosol and subsequent vasodilation. ${ }^{6}$ This combination of the antiplatelet and vasodilator activity of dipyridamole leads to improved tissue perfusion. ${ }^{7}$

Although much of the research conducted with dipyridamole is related to its coronary and thrombolytic mechanisms of action, adenosine inhibition, elevation of cAMP and cGMP levels, vasodilation and tissue perfusion are closely associated with many ocular disorders. As an example, cGMP levels are related to the production and drainage of aqueous humor. Artherosclerosis, vasculitis, and similar vascular dysregulations have been shown to play a role in the pathogenesis of normal-tension glaucoma. ${ }^{8,9}$ The Egna-Neumarkt study compared patients with diastolic perfusion pressures $<50 \mathrm{mmHg}$ to those with $65 \mathrm{mmHg}$ or higher, demonstrating a 4.5-fold increase in glaucoma prevalence in the group in the lower range. ${ }^{10}$ Retinal capillary nonperfusion or retinal ischemia is associated with branch or central vein occlusions in some patients and disc hemorrhages are a classic vascular manifestation of a change in perfusion of the tissue. Also, impaired ocular circulation can be prompted by numerous vascular diseases and has been treated with calcium channel blockers, serotonin antagonists, and platelet inhibitors.

Because of these types of associations, in addition to currently approved uses, dipyridamole has been used in the treatment of various ocular conditions and disorders. These

\footnotetext{
${ }^{1}$ Ocular Research Department, Center for Drug Repurposing, Ariel University, Ariel, Israel.

${ }^{2}$ Eye Research Program, MedInsight Research Institute, Hampshire, United Kingdom.

(C) Moshe Rogosnitzky et al. 2015; Published by Mary Ann Liebert, Inc. This Open Access article is distributed under the terms of the Creative Commons Attribution Noncommercial License (http://creativecommons.org/licenses/by-nc/4.0/) which permits any noncommercial use, distribution, and reproduction in any medium, provided the original author(s) and the source are credited.
} 
eye-related applications have previously been explored in smaller studies, case series, and reports. Studies have been performed, both in vivo and in humans, with the aim of assessing the efficacy of dipyridamole in treating various ocular conditions, as well as its safety, pharmacokinetic profile, and mechanism of action. Some studies delivered an evaluation of the effects of dipyridamole in ocular applications, as an indirect or secondary outcome, reporting evidence related to efficacy, safety, and acceptable dosing ranges. In this study, we review current understanding of the mechanisms by which dipyridamole exerts its effects on different ocular tissues, discuss the role of dipyridamole in clinical practice, and highlight areas of use.

\section{Preclinical investigation}

Meyer et al. investigated the effects of dipyridamole in isolated porcine ciliary arteries (diameter 200-250 microns) and found that the drug induces concentration-dependent relaxation with the vasodilator effect observed at $10^{-4} \mathrm{~mol} / \mathrm{L}$ dipyridamole. ${ }^{11}$ He suggested that the findings demonstrate the vasodilator properties of dipyridamole in porcine ciliary arteries and added that endothelial nitric oxide and prostacyclin made important contributions to these effects. He concluded that further study is needed to show whether the properties of dipyridamole may also occur in vivo and offer clinical benefit in patients with ocular vasospasms and other ophthalmic vascular dysfunctions.

Although dipyridamole can decrease the phosphodiesterase activity, it typically does not interfere with retinal cAMP levels. ${ }^{12}$ Estrade et al. used ex vivo model of isolated retina to study the effect of dipyridamole on retinal function assessing electroretinogram amplitudes. ${ }^{13}$ Dipyridamole had no effect on the retinal function at $10^{-5} \mathrm{~mol} / \mathrm{L}$ concentration, but changes in rat retina electroretinogram were observed at a concentration of $10^{-4} \mathrm{~mol} / \mathrm{L}$.

Qin and De Vries examined the mechanisms by which sublethal oxidative stress inhibits retinal pigment epithelial cell phagocytosis because reduction in photoreceptor outer segment load under oxidative stress might direct retinal pigment epithelial cells to a self-protected status, which in turn may be important in dry macular degeneration. ${ }^{14}$ They found that although the exact mechanism remained to be addressed, dipyridamole alone enhanced retinal pigment epithelial cell phagocytosis of the photoreceptor outer segment.

\section{Intravitreous administration}

Intravitreal injection has become paramount in the treatment of many vision-threatening diseases, making it one of the most common medical procedures performed across all specialties. Various pharmacotherapies, such as antibiotics, steroids, and antifungal and antiviral drugs are effectively delivered directly into the vitreous cavity by this method, treating a range of ocular pathologies. A number of animal studies have previously examined the effects of direct intravitreal administration of dipyridamole on the eye and its constituent tissues.

Campochiaro and Sen injected $0.1 \mathrm{~mL}$ doses of various adenosine agonists and putative vasodilating agents, including dipyridamole $10^{-3} \mathrm{~mol} / \mathrm{L}$, into the eyes of rabbits, marmosets, and cats. ${ }^{15}$ They observed prominent dilation within $1 \mathrm{~h}$ of intravitreal injection, becoming maximal after $5 \mathrm{~h}$, but not persisting for more than $24 \mathrm{~h}$. Dipyridamole, at a concentration of $10^{-3} \mathrm{~mol} / \mathrm{L}$, produced a prominent $36.9 \%$ $\pm 5.2 \%$ increase in retinal vein diameter $6 \mathrm{~h}$ after injection, which was resolved to $3.9 \% \pm 1.2 \% 24 \mathrm{~h}$ postinjection. When the authors considered the concentrations and volumes studied, they speculated that a significant portion of the injected drug likely exited the eye through an anterior route. Dilation was observed $1 \mathrm{~h}$ after injection, and may have occurred earlier, but this was the first time point studied. The maximal effect was noted $5 \mathrm{~h}$ after injection and persisted for several hours after, suggesting a relatively slow diffusion of dipyridamole through the vitreous, which is consistent with previous studies. ${ }^{16}$ Campochiaro and Sen noted that in some instances, the vascular dilation caused by dipyridamole was accompanied by small subhyaloid and intraretinal hemorrhages, producing a fundus image reminiscent of certain features of ischemic retinopathies. ${ }^{15}$

Braunagel et al. studied the effect of intravitreous injections of dipyridamole on ocular blood flow in rabbits. ${ }^{12}$ The injections of dipyridamole increased blood flow in all ocular tissues tested: iris, iris root-ciliary body, retina, and choroid. Each of the ocular tissues studied exhibited a different response to the concentration of dipyridamole injected, with the retina demonstrating the highest level of sensitivity. In the iris, dipyridamole caused an apparent dose-related increase in blood flow, however, this increase was not statistically significant until the dosage reached $5 \times 10^{-5} \mathrm{~mol} / \mathrm{L}$. In the ciliary body, blood flow was increased by dipyridamole at concentrations $\geq 5 \times 10^{-7} \mathrm{~mol} / \mathrm{L}$, with a maximal increase detected at $5 \times 10^{-6} \mathrm{~mol} / \mathrm{L}$. The profile of the response of the choroid was similar to that seen in the ciliary body. An increase in blood flow was observed in all tissues once concentrations of dipyridamole reached $\geq 5 \times 10^{-7} \mathrm{~mol} / \mathrm{L}$. The response of the retina differed from responses observed in the other ocular tissues tested, in that after 5 min there were significant increases in blood flow compared to control, but in contrast to the iris and iris root-ciliary body, the flow rates in the retina continued to increase after $15 \mathrm{~min}$. The increase in maximal blood flow observed at $5 \times 10^{-6} \mathrm{~mol} / \mathrm{L}$ concentration persisted for up to an hour postadministration. The authors determined that the increase in blood flow in the individual ocular tissues cannot be attributed to shunting or redistribution because as the total blood flow to the eye increased, the percentage of total flow to each individual tissue remained near control values.

\section{Injectable and oral administration}

The eye's response to an oral medication is reliant on many factors, all of which contribute to the drug's effective activity and concentration at the intended site of action. Due to the high potential of physiologic barriers associated with absorption of oral and/or parenterally administered medications for the eye, often other modes of delivery are preferred to supply medication quickly and effectively. That said, dipyridamole is most commonly administered in its oral tablet or intravenous solution forms and the ocular effects have been reported in several studies.

De La Cruz et al. have performed extensive studies on the use of oral administration of dipyridamole and effects on the retinal vasculature and crystalline lens in diabetic rat models. ${ }^{17-19}$ In early studies, they evaluated the effect of 
acetylsalicylic acid (ASA) alone and ASA plus dipyridamole on the retinal vascular pattern over 3 months in rats with experimental diabetes mellitus. Rats treated with ASA alone showed a continuous vascular bed, less tortuous vessels, and a reduction in prostacyclin production compared to untreated diabetic rats, whereas those treated with ASA plus dipyridamole showed a continuous vascular bed, scarce tortuous vessels, vascular diameters similar to controls, and normal prostacyclin production. Later, they compared the effects of dipyridamole, RA-642, and mopidamol on the platelet activity and thromboxane/prostacyclin balance in relation to the degree of retinal vascularization and on lenticular opacities in a model of experimental cataracts in diabetic rats. All 3 pyrimido-pyrimidine derivatives caused a statistically significant reduction of opacification in crystalline lens compared with untreated diabetic animals. The results demonstrated that dipyridamole caused a $90 \%$ increase in the aortic production of prostacyclin and treatment with dipyridamole caused a 2.5 -fold increase in the percentage of retinal surface occupied by peroxidase-labeled vessels. With regard to the anterior portion of the eye, they found that dipyridamole exerted a protective effect from free radical damage to the crystalline lens in the model of experimental diabetes and is the result of the antioxidant action of the compound.

Dipyridamole is commonly used in combination with aspirin as an antiplatelet agent. The DAMAD study (Dipyridamole, Aspirin, and Microangiopathy of Diabetes) was a large, multicenter, randomized controlled trial of aspirin alone or in combination with dipyridamole compared to placebo in patients with early diabetic retinopathy. ${ }^{20} \mathrm{~A}$ total of 475 patients with nonproliferative diabetic retinopathy were enrolled. Aspirin dosage was $1 \mathrm{~g} /$ day; dipyridamole dosage was $225 \mathrm{mg} /$ day ( $75 \mathrm{mg}$, thrice daily). Annual microaneurysm counts, based on fluorescein angiography, showed slower annual incrementation of microaneurysms in the treatment groups compared to placebo, which was statistically significant $(P=0.02)$.

Saldan's 60 patients (120 eyes) with diabetic angiopathy and retinopathy were receiving $75 \mathrm{mg}$ dipyridamole thrice daily, plus $0.5 \mathrm{~g}$ of aspirin every third day. ${ }^{22}$ The treatment for 30-45 days resulted in an improved hemocirculation of the eye and rheological properties of blood. Vision sharpness improved in 39 eyes. On an average, erythrocyte aggregation decreased by $25 \%$, blood flow improved by $40 \%$, and perivascular edema decreased by $30 \%$.

Kaiser et al. studied the influence of dipyridamole in a prospective open trial of 23 patients with impaired ocular circulation due to different causes, such as anterior ischemic optic neuropathy, vasospastic syndrome, glaucoma, or central retinal vein occlusion. ${ }^{23}$ Blood flow velocities in the ophthalmic artery, central retinal artery and vein, and 1 lateral and 1 medial posterior ciliary artery were measured before and during treatment with dipyridamole $(75 \mathrm{mg}, 3$ times daily). Dipyridamole increased blood flow velocities significantly in all vessels measured. The investigators predicted that evaluation of the effect of dipyridamole over a longer period in patients with impaired ocular blood flow might be promising.

A more recent study reported on the use of berlition (thioctic acid), $300 \mathrm{mg}$, in combination with dipyridamole (Curantyl) $50 \mathrm{mg}$, each twice daily for 3 months, in 54 type 2 diabetes patients with distal sensomotor diabetic polyneuropathy of low extremities and signs of retinopathy. ${ }^{24}$ The combination delivered a significant positive effect on the state of sensory and motor functions, as well as neurophysiologic disturbances, and a positive influence on the development of retinopathy was also observed in this cohort.

Honrubia et al. reported excellent results of dipyridamole on early treatment of retinal hemorrhages. ${ }^{25}$ The therapeutic effect was prominent in the treatment of central retinal artery branched thromboses and eyes with posterior pole injuries. A total of 58 patients included in the study suffered from one of the following conditions: obstruction of the central retinal artery or its branches, obstruction of the central retinal vein or its branches, spontaneous macular bleeding, vitreous hemorrhages, traumatic lesions of the posterior pole, consecutive hemorrhages associated with cryotherapy in retinal detachment surgery, or chronic simple glaucoma. All patients were treated with $150 \mathrm{mg}$ dipyridamole daily, divided into 3 oral doses and patients were followed for 1 year. Study assessments included evaluation of changes in visual acuity, complete ophthalmoscopy examination, and fluorescein angiography.

Podos studied the effect of intraperitoneal injections of dipyridamole $(100 \mathrm{mg} / \mathrm{kg})$ on ocular hypertension in rabbits. His results demonstrated an inhibition of ocular hypertension and rise of aqueous humor protein, induced by prostaglandin E2. ${ }^{26}$ As a large number of ocular inflammatory processes are mediated, in part, by prostaglandins, this direct inhibitory action of dipyridamole on the action of PGE2 observed in this study led Podos to suggest that dipyridamole may be useful in the treatment of ocular inflammatory disease. Notably, Podos failed to achieve benefit with topically administered dipyridamole.

Juárez et al. studied the effects of intraperitoneally injected dipyridamole in a rat and mouse model of oxygen-induced ischemic retinopathy to investigate whether commonly used vasodilating drugs ameliorate angiogenesis in experimental retinopathy of prematurity (ROP). ${ }^{27}$ They also looked at how different growth factors responded to these vasodilating drugs. They concluded that dipyridamole markedly inhibited angiogenesis in experimental ROP and growth factors were elevated in hypoxic conditions. Treated animals demonstrated significant decreases of PDGF, VEGF, and TGF-beta2 in retinal and vitreous tissues.

Suarez and Sanchez investigated the effect of intravenous administration of dipyridamole $(20 \mathrm{mg})$ on intraocular pressure and aqueous humor production. ${ }^{28}$ They reported no measurable effect on intraocular pressure 20-30 min postinjection. The aqueous humor production was increased in some cases; however, the effect was not uniform. The patients included in the study were suffering from sclero-hypertensive vascular syndrome, reactive sclerosis, atherosclerosis, senile involution, and other retinopathies. Dipyridamole was administered for early treatment of retinal hemorrhages. The authors concluded that dipyridamole produced excellent results in the early treatment of retinal hemorrhages. The drug's therapeutic effect was prominent in treating thrombosed branches of the central retinal artery.

\section{Topical applications}

Topical ophthalmic medications are often the preferred mode of quick and efficient delivery of medication to the 
Table 1. Dipyridamole Studies for Ocular Disorders, Summary of Preclinical and Clinical Findings

\begin{tabular}{|c|c|c|c|c|c|}
\hline Condition treated & $\begin{array}{c}\text { Clinical/ } \\
\text { preclinical }\end{array}$ & $\begin{array}{c}\text { Route of } \\
\text { administration }\end{array}$ & Dosage & Conclusion & References \\
\hline Vasodilation effect & Preclinical & Intravitreal & $\begin{array}{l}0.1 \mathrm{~mL} \text {, } \\
\text { concentration } \\
10^{-3} \mathrm{~mol} / \mathrm{L}\end{array}$ & $\begin{array}{l}\text { Dipyridamole, at a } \\
\text { concentration of } 10^{-3} \\
\text { mol/L, produced a prominent } \\
36.9 \% \pm 5.2 \% \text { increase in } \\
\text { retinal vein diameter } 6 \mathrm{~h} \\
\text { after injection, which was } \\
\text { resolved to } 3.9 \% \pm 1.2 \% 24 \mathrm{~h} \\
\text { post injection. }\end{array}$ & 16 \\
\hline $\begin{array}{l}\text { Ocular blood flow- } \\
\text { iris, iris root-ciliary } \\
\text { body, retina and } \\
\text { choroid }\end{array}$ & Preclinical & Intravitreal & $\begin{array}{l}0.25 \% \text { dissolved in } \\
40 \% \text { polyethylene } \\
\text { glycol (MW 200) }\end{array}$ & $\begin{array}{l}\text { Ocular blood flow increased in } \\
\text { all ocular tissues tested: iris, } \\
\text { iris root-ciliary body, retina } \\
\text { and choroid. }\end{array}$ & 12 \\
\hline $\begin{array}{l}\text { Platelet activity and } \\
\text { thromboxane/ } \\
\text { prostacyclin balance } \\
\text { in relation to the } \\
\text { degree of retinal } \\
\text { vascularization } \\
\text { and on lenticular } \\
\text { opacities }\end{array}$ & $\begin{array}{l}\text { Preclinical } \\
\text { diabetic } \\
\text { model }\end{array}$ & Oral & $12 \mathrm{mg} / \mathrm{kg}$ daily & $\begin{array}{l}\text { Statistically significant } \\
\text { reduction of opacification in } \\
\text { crystalline lens compared } \\
\text { with untreated diabetic } \\
\text { animals. } 90 \% \text { increase in } \\
\text { aortic production of } \\
\text { prostacyclin. } 2.5 \text {-fold } \\
\text { increase in the percentage of } \\
\text { retinal surface occupied by } \\
\text { peroxidase-labeled vessels. } \\
\text { Protective effect from free } \\
\text { radical damage to the } \\
\text { crystalline lens. }\end{array}$ & $17-19$ \\
\hline $\begin{array}{l}\text { Early diabetic } \\
\text { retinopathy }\end{array}$ & Clinical & Oral & $\begin{array}{l}225 \mathrm{mg} / \mathrm{day}(75 \mathrm{mg}, \\
3 \text { times daily) }\end{array}$ & $\begin{array}{l}\text { Slower annual incrementation } \\
\text { of microaneurysms } \\
\text { compared to placebo. }\end{array}$ & 20 \\
\hline Diabetic retinopathy & Clinical & Oral & $\begin{array}{l}225 \mathrm{mg} / \mathrm{day}(75 \mathrm{mg} \text {, } \\
3 \text { times daily) }\end{array}$ & $\begin{array}{l}\text { Improved hemocirculation of } \\
\text { the eye and rheological } \\
\text { properties of blood. Vision } \\
\text { sharpness improved in } 39 \\
\text { eyes. Erythrocyte } \\
\text { aggregation decreased by } \\
25 \%, \text { blood flow improved } \\
\text { by } 40 \% \text {, and perivascular } \\
\text { edema decreased by } 30 \% \text {. }\end{array}$ & 21 \\
\hline Ocular circulation & Clinical & Oral & $\begin{array}{l}225 \mathrm{mg} / \mathrm{day}(75 \mathrm{mg} \text {, } \\
3 \text { times daily) }\end{array}$ & $\begin{array}{l}\text { Increased blood flow velocities } \\
\text { significantly in all vessels } \\
\text { measured. }\end{array}$ & 22 \\
\hline $\begin{array}{l}\text { Type } 2 \text { diabetes with } \\
\text { distal sensomotor } \\
\text { diabetic polyneuro- } \\
\text { pathy of low } \\
\text { extremities and signs } \\
\text { of retinopathy }\end{array}$ & Clinical & Oral & $\begin{array}{l}\text { Berlition (thioctic } \\
\text { acid), } 300 \mathrm{mg} \text {, } \\
\text { dipyridamole } \\
\text { (Curantyl) } 50 \mathrm{mg}, \\
\text { twice daily for } 3 \\
\text { months }\end{array}$ & $\begin{array}{l}\text { Significantly positive effect on the } \\
\text { state of sensory and motor } \\
\text { functions, as well as } \\
\text { neurophysiologic disturbances, } \\
\text { and a positive influence on the } \\
\text { development of retinopathy } \\
\text { were also observed. }\end{array}$ & 23 \\
\hline $\begin{array}{l}\text { Retinal hemorrhages } \\
\text { due to central retinal } \\
\text { artery branched } \\
\text { thromboses and eyes } \\
\text { with posterior pole } \\
\text { injuries }\end{array}$ & Clinical & Oral & $\begin{array}{l}150 \mathrm{mg} / \mathrm{day}(50 \mathrm{mg} \text {, } \\
3 \text { times daily) }\end{array}$ & $\begin{array}{l}\text { Excellent therapeutic effect } \\
\text { observed in early treatment } \\
\text { of retinal hemorrhages due to } \\
\text { central retinal artery } \\
\text { branches thromboses and } \\
\text { posterior pole injuries. }\end{array}$ & 24 \\
\hline Ocular hypertension & Preclinical & $\begin{array}{l}\text { Intraperitoneal } \\
\text { injection }\end{array}$ & $100 \mathrm{mg} / \mathrm{kg}$ & $\begin{array}{l}\text { Inhibition of ocular } \\
\text { hypertension and rise of } \\
\text { aqueous humor protein, } \\
\text { induced by prostaglandin E2. }\end{array}$ & 25 \\
\hline
\end{tabular}


TABle 1. (CONTINUED)

\begin{tabular}{|c|c|c|c|c|c|}
\hline Condition treated & $\begin{array}{c}\text { Clinical/ } \\
\text { preclinical }\end{array}$ & $\begin{array}{c}\text { Route of } \\
\text { administration }\end{array}$ & Dosage & Conclusion & References \\
\hline $\begin{array}{c}\text { Retinopathy of } \\
\text { prematurity }\end{array}$ & Preclinical & $\begin{array}{l}\text { Intraperitoneal } \\
\text { injection }\end{array}$ & & $\begin{array}{l}\text { Marked inhibition of } \\
\text { angiogenesis. Significant } \\
\text { decreases of PDGF, VEGF, } \\
\text { and TGF-beta } 2 \text { in retinal and } \\
\text { vitreous tissues. }\end{array}$ & 26 \\
\hline Retinal hemorrhages & Clinical & Intravenous & $20 \mathrm{mg}$ & $\begin{array}{l}\text { Excellent results in the early } \\
\text { treatment of retinal } \\
\text { hemorrhages with prominent } \\
\text { therapeutic effect in treating } \\
\text { thrombosis branches of the } \\
\text { central retinal artery. }\end{array}$ & 27 \\
\hline Ocular hypertension & Preclinical & Topical & $\begin{array}{l}2 \text { drops of } 5 \% \\
\text { suspension }\end{array}$ & $\begin{array}{l}\text { No effect on the artificially } \\
\text { induced (by prostaglandin } \\
\text { E2) ocular hypertension. }\end{array}$ & 25 \\
\hline Ocular hypertension & Preclinical & Topical & $\begin{array}{l}\text { Varying } \\
\text { concentrations } \\
\text { from } 0.00005 \% \\
\text { to } 0.5 \%\end{array}$ & $\begin{array}{l}\text { Reduction of intraocular } \\
\text { pressure was achieved in } \\
1-2 \mathrm{~h} \text {, and results were } \\
\text { concentration dependent. }\end{array}$ & 28 \\
\hline Pterygium & Clinical & Topical & $\begin{array}{l}1.68 \times 10^{-4} \mathrm{~mol} / \mathrm{L} \text { in } \\
\text { normal saline } \\
\text { solution } 1 \text { drop } \\
\text { twice daily. } \\
\text { Tapered over } \\
1 \text { year }\end{array}$ & $\begin{array}{l}\text { Marked improvement to } \\
\text { pterygium and associated } \\
\text { symptoms. }\end{array}$ & 29 \\
\hline
\end{tabular}

MW, molecular weight.

eye. The specific features of an eye drop's pharmacologic design help to ensure its acceptability to the patient, its bioavailability, and its respective efficacy at the intended site of action. Characteristics such as $\mathrm{pH}$, osmolality, particle size, and PKa balance influence how effectively a topically applied drug will penetrate through the ocular surface and into the eye. The $\mathrm{pH}$ of a topical ophthalmic formulation is preferably between 5.0 and 8.0, although some with a $\mathrm{pH}$ as low as 3.0 are acceptable because the $\mathrm{pH}$ will rapidly approximate to that of lacrimal fluid upon instillation. Topical ocular indications of dipyridamole have not been sufficiently studied in humans, but the experimental data from animal models suggest minimal associated side effects and/or complications, which have been limited to transient minimal irritation at higher concentrations $(0.5 \%$ in rabbits $)$ and no observed effect on heart rate, blood pressure, or respiratory system.

The early work from Podos found that topical application of dipyridamole ( 2 drops of $5 \%$ suspension) in rabbits had no effect on the artificially induced (by prostaglandin E2) ocular hypertension. ${ }^{26}$

Miyazaki and Tanaka examined a method for treatment of ocular hypertension and glaucoma based on the use of dipyridamole eye drops. ${ }^{29}$ The ocular hypotensive effect was investigated in rabbits treated with eye drops containing 6 concentrations of dipyridamole that ranged from $0.00005 \%$ to $0.5 \%$ (equivalent to maximal concentration of $5 \mathrm{~g} / \mathrm{L}$, or $\sim 0.01 \mathrm{~mol} / \mathrm{L})$. Maximal reduction of intraocular pressure was achieved in 1-2 $\mathrm{h}$, and results were concentration dependent. The hypotensive effect lasted for $6 \mathrm{~h}$ after administration, and for concentrations ranging from $0.001 \%$ to $0.5 \%$, the effect remained unchanged for $6 \mathrm{~h}$ after instillation. The effect was similar or superior to commercially used timolol maleate $0.5 \%$ eye drops. Eye irritation tests revealed that at the highest used concentration $(0.5 \%)$, slight congestion in the iris was observed at $0.5 \mathrm{~h}$ after instillation. The congestion disappeared after $6 \mathrm{~h}$. The effect was not clinically significant since the increased amount of intraocular blood flow is desirable in the treatment of glaucoma. There were no noticeable changes in other eye irritation measures. The $\mathrm{pH}$ range of eye drop preparations varied from 3.0 to 8.0 (preferred range 5.0-8.0). The typical single dosage was 1-3 drops, $25 \mu \mathrm{g}$ to $6 \mathrm{mg}$, and was administered 1-4 times daily. The authors recommend that the dosage and administration can vary depending on patients' conditions and age. The drug is considered to be free of hypotensive, brachycardiac, and respiratory side effects associated with beta-blockers used in eye drops.

Most recently, Carlock et al. reported a case of pterygium that was treated using topical dipyridamole rather than surgical intervention. ${ }^{30}$ At the initial presentation, the pterygium was staged at stage II to III, V3, C3, K2, and P1 (using Johnston, Williams \& Sheppard's classification). Treatment with topically applied dipyridamole $\left(1.68 \times 10^{-4} \mathrm{~mol} / \mathrm{L}\right.$ in normal saline solution) was initiated, starting with 1 drop twice daily to the affected area, later reduced to 1 drop daily, and then further reduced over the reported duration of 1 year. The patient experienced a marked improvement in both the pterygium, graded as stage 0 to $\mathrm{I}, \mathrm{V} 0, \mathrm{C} 2, \mathrm{~K} 0, \mathrm{P} 0$, and associated symptoms. The tissue regressed from the limbal region of the cornea and decreased in length and height. Conjunctival hyperemia and vascularization resolved and the underlying scleral vessels could once again be visualized. No systemic side effects or eye irritation related to the dipyridamole was reported. 


\section{Conclusions}

With a long history of successful applications in various fields of medicine, dipyridamole has an established safety record. Potential complications and side effects of this drug are well known and documented. Generally, oral administration of dipyridamole has been well tolerated, although ischemia and angina have been reported. Cardiovascular symptoms have been the most frequently reported adverse effects associated with dipyridamole, particularly when given intravenously.

The drug is available in various forms suitable for different routes of administration. Dipyridamole is chemically stable upon prolonged storage in both solid (pills) and liquid (solutions for injection, oral liquid formulations) forms.

When it comes to ocular applications, no significant side effects were reported thus far in the literature, although for the majority of published ocular applications, the drug was administered either orally or intravitreally (Table 1). In regard to the topical ocular applications (eye drops), existing research is limited. Data collected from several studies indicate that there is a low likelihood of observing serious side effects with this administration route, specifically within the concentration range in the millimolar level or lower. There are studies in advanced planning to treat keratoconjunctivitis sicca, pterygium, and pinguecula. Further study is needed to determine the interaction propensity of topically administered dipyridamole with other common eye drops.

Based on studies performed to date, dipyridamole seems poised to play a role in treating ocular hypertension, glaucoma, inflammatory eye disorders, retinal vascular disorder, pterygia, and dry eye disease. Robust studies are required to permit repurposing of this long-approved antianginal drug for treating eye disorders, especially for topical application.

\section{Author Disclosure Statement}

The authors have no proprietary interest in the materials used in this study. M.R. owns intellectual property relating to topical dipyridamole use for treating anterior segment eye disorders.

\section{References}

1. Melani, A., Cipriani, S., Corti, F., and Pedata, F. Effect of intravenous administration of dipyridamole in a rat model of chronic cerebral ischemia. Ann. N. Y. Acad. Sci. 1207: 89-96, 2010.

2. Kim, H.H., and Liao, J.K. Translational therapeutics of dipyridamole. Arterioscler. Thromb. Vasc. Biol. 28:s39s42, 2008.

3. Yip, S., and Benavente, O. Antiplatelet agents for stroke prevention. Neurotherapeutics. 8:475-487, 2011.

4. Verro, P., Gorelick, P.B., and Nguyen, D. Aspirin plus dipyridamole versus aspirin for prevention of vascular events after stroke or TIA: a meta-analysis. Stroke. 39:1358-1363, 2008.

5. Chakrabarti, S., and Freedman, J.E. Dipyridamole, cerebrovascular disease, and the vasculature. Vascul. Pharmacol. 48:143-149, 2008.

6. Meijer, P., Oyen, W.J., Dekker, D., van den Broek, P.H., Wouters, C.W., Boerman, O.C., Scheffer, G.J., Smits, P., and Rongen, G.A. Rosuvastatin increases extracellular adenosine formation in humans in vivo: a new perspective on cardiovascular protection. Arterioscler. Thromb. Vasc. Biol. 29:963-968, 2009.

7. Chakrabarti, S., Vitseva, O., Iyu, D., Varghese, S., and Freedman, J.E. The effect of dipyridamole on vascular cellderived reactive oxygen species. J. Pharmacol. Exp. Ther. 315:494-500, 2005.

8. Kerr, N.M., and Danesh-Meyer, H.V. Phosphodiesterase inhibitors and the eye. Clin. Experiment. Ophthalmol. 37: 514-523, 2009.

9. Flammer, J., Guthauser, U., and Mahler, M. Do ocular vasospasm help to cause low-tension glaucoma? Doc. Ophthalm. Proc. Series. 49:3979, 1987.

10. Bonomi, L., Marchini, G., Marraffa, M., Bernardi, P., Morbio, R., and Varotto, A. Vascular risk factors for primary open angle glaucoma: the Egna-Neumarkt study. Ophthalmology. 107:1287-1293, 2000.

11. Meyer, P., Flammer, J., and Lücher, T.F. Effect of dipyridamole on vascular responses of porcine ciliary arteries. Curr. Eye Res. 15:387-393, 1996.

12. Braunagel, S.C., Xiao, J.G., and Chiou, G.C. The potential role of adenosine in regulating blood flow in the eye. $J$. Ocul. Pharmacol. 4:61-73, 1988.

13. Estrade, M., Grondin, P., Cluzel, J., Bonhomme, B., and Doly, M. Effect of a cGMP-specific phosphodiesterase inhibitor on retinal function. Eur. J. Pharmacol. 352:157163, 1998.

14. Qin, S., and De Vries, G.W. alpha2 But not alpha1 AMPactivated protein kinase mediates oxidative stress-induced inhibition of retinal pigment epithelium cell phagocytosis of photoreceptor outer segments. J. Biol. Chem. 283:67446751, 2008.

15. Campochiaro, P.A., and Sen, H.A. Adenosine and its agonists cause retinal vasodilation and hemorrhages. Implications for ischemic retinopathies. Arch. Ophthalmol. 107:412-416, 1989.

16. Fredholm, B.B., and Hedqvist, P. Modulation of neurotransmission by purine nucleotides and nucleosides. Biochem. Pharmacol. 29:1635-1643, 1980.

17. De La Cruz, J.P., Moreno, A., Mérida, F., García Campos, J., and Sánchez de la Cuesta, F. The pyrimido-pyrimidine derivatives, dipyridamole, mopidamol and RA-642, prevent from retinal vascular defects in experimental diabetes mellitus. Thromb. Res. 81:327-337, 1996.

18. De la Cruz, J.P., Sintas, A., Moreno, A., Garcia-Campos, J., and Sanchez de la Cuesta, F. Dipyridamole and RA-642 inhibit the production of superoxide anion and free radical damage to rat lens. Pharmacol. Toxicol. 69:201-204, 1991.

19. De la Cruz, J.P., Moreno, A., Mérida, F., García-Campos, J., and Sánchez de la Cuesta, F. The pyrimido-pyrimidine derivatives, dipyridamole and RA-642, reduce opacification of crystalline lens in diabetic rats. Pharmacol. Toxicol. 75:250-254, 1994.

20. The DAMAD Study Group. Effect of aspirin alone and aspirin plus dipyridamole in early diabetic retinopathy. A multicenter randomized controlled clinical trial. The DAMAD Study Group. Diabetes. 38:491-498, 1989.

21. Saldan, I.R. Use of disaggregants in treating diabetic retinopathy. Oftalmol. Zh. 7:395-398, 1984.

22. Kaiser, H.J., Stümpfig, D., and Flammer, J. Short-term effect of dipyridamole on blood flow velocities in the extraocular vessels. Int. Ophthalmol. 19:355-358, 1995.

23. Al-Zamil MKh. The use of dipyridamole (curantyl) in combination with alpha-lipoic acid in the treatment of di- 
abetic neuropathy with retinopathy. Zh. Nevrol. Psikhiatr. Im. S. S. Korsakova. 108:23-26, 2008.

24. Honrubia, F.M., Francés, J.B., and Pérez Salvador, J.L. Estudio del dipiramidol en la patología vascular retiniana. Arch. Soc. Esp. Oftalmol. 34:1127-1133, 1974.

25. Podos, S.M. Effect of dipyridamole on prostaglandininduced ocular hypertension in rabbits. Invest. Ophthalmol. Vis. Sci. 18:646-648, 1979.

26. Juárez, C.P., Muiño, J.C., Guglielmone, H., Sambuelli, R., Echenique, J.R., Hernández, M., and Luna, J.D. Experimental retinopathy of prematurity: angiostatic inhibition by nimodipine, ginkgo-biloba, and dipyridamole, and response to different growth factors. Eur. J. Ophthalmol. 10:51-59, 2000.

27. Cuéllar Suárez, A., and García Sánchez, J. Tonographic changes caused by dipyridamol. Rev. Esp. Otoneurooftalmol. Neurocir. 28:75-82, 1969.

28. Miyazaki, H.H., and Tanaka, H. Method of reducing elevated intraocular pressure. US Patent 5428030, 1995.
29. Carlock, B.H., Bienstock, C.A., and Rogosnitzky, M. Pterygium: nonsurgical treatment using topical dipyridamole - a case report. Case Rep. Ophthalmol. 5:98-103, 2014.

Received: September 16, 2015 Accepted: October 28, 2015

Address correspondence to: Moshe Rogosnitzky Ocular Research Department Center for Drug Repurposing Ariel University

Ariel 40700

Israel

E-mail: moshero@ariel.ac.il 